\title{
Income Inequality and Socio-Political \\ Instability in Sub-Saharan Africa
}

Jean Michel Roy Oualy

University of Macerata, Italy

j.oualy@studenti.unimc.it

In this paper, we analyse the impact of income inequality on Socio-Political Instability (hereinafter SPI) in Sub-Saharan Africa from 1990 to 2018 with a sample of 47 countries. We first present the theoretical and empirical debate on income inequality and SPI. This literature review allows us to measure SPI using the principal component analysis method and hierarchical clustering and partitioning to analyse the similarities and differences between countries from a multidimensional perspective. We then estimate the SPI concerning income inequality and democracy. The findings are that assassinations are not linked to a regime's duration, and the duration of a regime reduces if coups détat (successful or not) are rampant. Between democracy and income inequality, the former has 34 times more impact on SPI. GDP growth increases SPI and education reduces SPI.

Key Words: income inequality, democracy, socio-political instability, political regime, Sub-Saharan African countries JEL Classification: D74, P16

(c) Br.SA https://doi.org/10.26493/1854-6935.19.49-72

\section{Introduction}

According to economic theory, income inequality is one of the principal causes of Socio-Political Instability (hereinafter SPI). In more unequal societies, the motive that drives people to rise up is the demand for a fair share of economic resources. Populations from the same tribe, belonging to the same religion or sharing the same political ideology, engage in violent protests, demonstrations, unrest, assassinations, rebellions and coups détat to claim their share of the country's wealth. We can cite the case of South Africa, Rwanda, Liberia, Nigeria or Casamance (Senegal). That is why Alesina and Perotti $(1996,1205)$ said: 'More unequal societies are more politically unstable.'

Government use all means, such as intimidation, imprisonment of opponents, confiscation of the press, and prohibition of public demonstrations, to impose their ideas. Poor people, ${ }^{1}$ who constitute much of the 
population in Sub-Saharan African (hereinafter ssA) countries, use violence to express themselves and assert their rights. They carry out strikes, repeated demonstrations, breakages, and disturb public order to be heard. Anne Krueger, first deputy managing director of the International Monetary Fund in 1997, said that poor people are ready to do anything to improve their material conditions in a situation of high inequality (Krueger 2002). Based on the high levels of income inequality ${ }^{2}$ coupled with frequent SPI (demonstrations, wars, killings, terrorisms, rebellions, coups d'état) in SsA, it is imperative to examine the social, economic and political cost of such phenomena.

Hitherto, some authors have studied the relationship between economic outcomes and political instability. The most used economic variables are GDP growth and investment. Barro (1991; 1999), Kormendi and Meguire (1985) and Alesina et al. (1996) found that SPI reduces growth. According to Cukierman, Edwards, and Tabellini (1992), SPI has instability effects on inflation. For Alesina and Perotti (1996), Keefer and Knack (2000), Perotti (1996) and Fosu (1992; 2002), SPI is the channel through which inequality harms investment and growth because SPI creates economic uncertainty and disrupts production activities.

In this regard, the paper's objective, which ties in with its contribution to the literature, is to analyse the impact of income inequality on SPI in ss A countries. Additionally, the impact of democracy on SPI is also empirically examined. The author is confident that findings from this research will inform policy making and extend the boundaries of academic research. To the best of our knowledge, the relationship between income inequality and SPI in SSA has not yet been an object of research. The paper's contributions are enumerated as follows:

- The research uses a new methodology, Hierarchical Clustering on Principal Components, to build the SPI index to study the similarities and differences between countries concerning SPI. This approach is a novel idea.

- The study covers 47 ss a countries for an extended time frame from 1990-2018.

Findings showed that a political regime's longevity does not trigger killings, and the duration of a regime reduces if coups détat (successful or not) are rampant. Further evidence suggests that democracy explains SPI more than income inequality does, that GDP growth increases SPI and that education reduces SPI. 
The rest of this paper is structured as follows. The next section (the literature review) builds the SPI index using the Principal Component Analysis (hereinafter PCA) method and presents the theoretical and empirical debate on income inequality and SPI. The methodology estimates the SPI in relation to income inequality, democracy and controlled variables. At the end, we have the conclusion.

\section{Literature Review}

\section{SOCIO-POLITICAL INSTABILITY CONCEPT}

SPI refers to troubles and crises: at a social level - demonstrations, bad social cohesion, terrorism, genocide, economic level - destruction of goods and economic infrastructures, reduction of production, and political level - imprisonment, coups d'état, assassinations, civil war, rebellion (Hibbs 1973; Alesina et al. 1996; Acemoglu and Robinson 2001). There are three approaches to SPI.

The first approach is the measure of SPI by a dichotomous variable. Fosu (1992) uses a binary variable to estimate the impact of political instability on ss a growth. A study carried out on Côte d'Ivoire, Kouakou (2010), calculates the index of political instability using a binary variable. The index takes the value 1 in the event of political instability and o otherwise. Lalime (2010) uses an indicator variable which takes the value 1 if at least one of the typical characteristics of political instability has been observed and o otherwise. These characteristics are coups d'état, political assassinations, untimely demonstrations, political protests and strikes, arrests, political repression and military spending.

This approach (measuring political instability by a binary variable of $\mathrm{o}$ and 1 ) has the disadvantage of giving the same weight, or even the same impact, to all the variables that constitute the political instability. Some of them, like genocide, have much greater impact than others (mere protests). This dichotomous measure of instability does not fully exploit all the informational values of SPI.

The second approach to measuring SPI highlights the frequency of regime change. These changes can be constitutional, thus happen according to the law, or unconstitutional, that is, occur from a coup d'état. A high propensity for executive change results in high political instability. This propensity to government changes is measured by probit regressions in which the probability of a change in the executive is related to several economic, socio-political and institutional variables. Angelopoulos and 
Economides (2008), Beck, Levine, and Loayza (2000), Treisman (2000), Cukierman, Edwards, and Tabellini (1992) and Edwards and Tabellini (1991) adopt this definition of instability in their work.

The third approach to measuring political instability does not directly relate to the changes in executive power. It is constructing an index that sums up various variables that capture social unrest and political violence using PCA. This approach is implemented by Hibbs (1973), Fosu (1992) and Alesina and Perotti (1996). ${ }^{3}$

The advantage of this method lies in the fact that it makes it possible to identify variables that best explain the largest possible part of SPI variability. We could have collinearity between the variables because they are closely related. The proximity of the variables comes from the fact that they explain the same phenomenon. Correlation between variables means repeating the information. The PCA method makes it possible to sort the information and retains as much information as possible. ${ }^{4}$

A reference for the political instability index calculated with PCA is Hibbs (1973). It builds the collective protest index using riots, antigovernment demonstrations and political strikes.

Barro (1991), one of the first to measure political instability, does so simply by using the number of assassinations (expressed in millions of population per year) and the occurrence of violent revolutions and coups (per year). He finds that the frequency of coups and the number of political assassinations negatively influence growth.

Alesina and Perotti (1996) extend Barro's (1991) approach to explain political instability better. They use PCA to build a weighted average of variables that capture political unrest: mass violence, political assassinations, coups détat and a measure of dictatorship. The choice of these variables is to capture the idea of political instability as a danger to private law. Alesina and Perotti (1996) built their SPI index using Gupta's (1990) data from 1960 to 1985.

The SPI index of Alesina and Perotti (1996) and that of Gupta (1990) differ in three aspects: the country samples are different; Gupta (1990) used discriminant analysis; and he includes many more variables (the number of political demonstrations against a government, the number of riots, the number of political strikes, the number of politically motivated attacks, the number of political executions). Despite these differences, the two indices are $83 \%$ correlated. Fosu (2002) also used the PCA method to build SPI. He used the frequencies of coups d'état, involuntary changes of government, aborted coups and failed coups. 
BILATERAL RELATIONSHIP BETWEEN INCOME INEQUALITY AND SPI

The relationship between income inequality and SPI is bidirectional. The literature suggests that SPI is caused by inequality. Dutt and Devashish (2008) argued that most ss A countries have significant natural resources, but the income from these resources is diverted by the ruling powerful elites.

In cases of large inequalities, election results are unreliable due to the wealthy and lobbyists (Krugman 2007). Kaufmann, Kraay, and ZoidoLobaton (1999), using the Worldwide Governance Indicators, found that, as a general rule, unequal societies are much more prone to political instability, they are subjected to violence, coups détat, etc.

Like Alesina and Perotti (1996), Dutt and Devashish (2008) conclude that inequality is positively correlated with political instability. They find significant and robust results.

Reducing inequalities is very beneficial for the economy, social cohesion and peace. Many authors defend this thesis (Dabla-Norris et al. 2015; Persson and Tabellini 2000; Venieris and Gupta 1986).

SPI is also caused by inequality. Several studies showed a difference in the allocation of resources among favourable and unfavourable areas to the ruling party (Lindbeck and Weibull 1987; Dixit and Londregan 1996; 1998; Bardhan and Mookherjee 2010). This is the case in India, where, after the elections, partisan districts received transfers that are more than $16 \%$ greater than those of non-partisan districts (Arulampalam, Devereux, and Maffini 2010).

The SPI evolved during a recession and economic instability. Gasiorowski (1995) and Przeworski et al. (1996) show that recessions significantly increase coups. This was the case for Brazil in 1964, Chile in 1973 and Argentina in 1976, to mention a few. On the other hand, rich countries (Norway, Iceland, Sweden) consolidated their democracy thanks to their stability. These authors point out that ss A countries, which are poor, have SPI because of economic instability.

According to Bourguignon and Morrisson (1998), levels of violence, as measured by homicide rates, have increased sharply in the two most unequal regions of the world (Latin America and ss A), and less in regions where growth is the fastest (Eastern Europe, Russia and Central Asia).

Addressing the issues of instability and its consequences for economic development, Collier (2007) shows that $73 \%$ of the poorest countries have 
TABLE 1 Variables of Equation (1)

\begin{tabular}{|c|c|c|}
\hline Variable & Description & Source \\
\hline SCOUP1 & Successful coup détat & \multirow{7}{*}{$\begin{array}{l}\text { Center for systemic } \\
\text { peace }\end{array}$} \\
\hline ATCOUP2 & Attempted coup d'état & \\
\hline PCOUP3 & Coup d'état plots & \\
\hline AGCOUP & $\begin{array}{l}\text { Subversion of the constitutional order } \\
\text { and the imposition of an autocratic regime }\end{array}$ & \\
\hline REBOUTEX & $\begin{array}{l}\text { Rebel forces fighting against forces } \\
\text { loyal to the regime }\end{array}$ & \\
\hline ASSASSEX & Assassination of executive & \\
\hline DURABLE & Regime durability & \\
\hline NDEATH & Number of persons killed in an event & \multirow{2}{*}{$\begin{array}{l}\text { Social conflict } \\
\text { analysis database }\end{array}$} \\
\hline REPRESS & $\begin{array}{l}\text { Government uses repression or violence } \\
\text { against participants in an event }\end{array}$ & \\
\hline NKILL & $\begin{array}{l}\text { Number of total confirmed fatalities } \\
\text { caused by terrorists }\end{array}$ & $\begin{array}{l}\text { Global terrorism } \\
\text { database }\end{array}$ \\
\hline
\end{tabular}

recently experienced a civil war. According to this study, the causality between poverty and political instability is a two-way street. Londregan and Poole $(1990 ; 1991)$ argue that there is a positive correlation between political instability and poverty: poor countries are unstable because they fail to get rich, and they fail to get rich because they are politically unstable.

\section{Methodology}

\section{MEASURE OF SOCIO-POLITICAL INSTABILITY \\ USING THE PCA METHOD}

The variables used to build the SPI index are as follows:

$$
\begin{aligned}
\operatorname{SPI}_{i t}= & \tau_{1} \text { SCOUP }_{i t}+\tau_{2} \text { ATCOUP }_{i t}+\tau_{3} \text { PCOUP }_{i t}+\tau_{4} \text { AGCOUP }_{i t} \\
& +\tau_{5} \text { REBOUTEX }_{i t}+\tau_{6} \text { ASSASSEX }_{i t}+\tau_{7} \text { DURABLE }_{i t} \\
& +\tau_{8} \text { NDEATH }_{i t}+\tau_{9} \text { REPRESS }_{i t}+\tau_{1} \text { ONKILL }_{i t} .
\end{aligned}
$$

Alesina and Perotti (1996) use five variables to build the SPI index using the PCA method. ${ }^{5}$ To these variables, we add the other five variables to consider the specificity of ss a countries. Presidents, at the end of their mandate, change the constitution to continue staying in power. The other concepts we take into account are the rebellions and terrorism which are numerous in ss A: the terrorism in the Sahel region (Burkina- 
TABLE 2 The Country List

\begin{tabular}{|c|c|c|c|}
\hline C Code & Countries & C Code & Countries \\
\hline $1 \mathrm{AGO}$ & Angola & $25 \mathrm{LSO}$ & Lesotho \\
\hline 2 BEN & Benin & $26 \mathrm{LBR}$ & Liberia \\
\hline 3 BWA & Botswana & $27 \mathrm{MDG}$ & Madagascar \\
\hline $4 \mathrm{BFA}$ & Burkina Faso & 28 MWI & Malawi \\
\hline 5 B DI & Burundi & 29 MLI & Mali \\
\hline $6 \mathrm{CPV}$ & Cabo Verde & 30 MUS & Mauritius \\
\hline $7 \mathrm{CMR}$ & Cameroon & $31 \mathrm{MOZ}$ & Mozambique \\
\hline $8 \mathrm{CAF}$ & Central African Republic & 32 NAM & Namibia \\
\hline 9 TCD & Chad & 33 NER & Niger \\
\hline $10 \mathrm{COM}$ & Comoros & 34 NGA & Nigeria \\
\hline $11 \mathrm{COD}$ & Congo, Democratic Rep. of the & 35 RWA & Rwanda \\
\hline $12 \mathrm{COG}$ & Congo, Republic of the & 36 sтP & Sao Tome and Principe \\
\hline $13 \mathrm{CIV}$ & Côte d'Ivoire & 37 SEN & Senegal \\
\hline $14 \mathrm{DJI}$ & Djibouti & $38 \mathrm{syc}$ & Seychelles \\
\hline $15 \mathrm{GNQ}$ & Equatorial Guinea & $39 \mathrm{SLE}$ & Sierra Leone \\
\hline 16 ERI & Eritrea & $40 \mathrm{som}$ & Somalia \\
\hline $17 \mathrm{swz}$ & Eswatini & $41 \mathrm{ZAF}$ & South Africa \\
\hline $18 \mathrm{ETH}$ & Ethiopia & $42 \mathrm{SDN}$ & Sudan \\
\hline $19 \mathrm{GAB}$ & Gabon & $43 \mathrm{TZA}$ & Tanzania \\
\hline $20 \mathrm{GMB}$ & Gambia, The & $44 \mathrm{TGO}$ & Togo \\
\hline $21 \mathrm{GHA}$ & Ghana & 45 UGA & Uganda \\
\hline 22 GIN & Guinea & $46 \mathrm{zMB}$ & Zambia \\
\hline $23 \mathrm{GNB}$ & Guinea-Bissau & $47 \mathrm{ZWE}$ & Zimbabwe \\
\hline $24 \mathrm{KEN}$ & Kenya & & \\
\hline
\end{tabular}

Faso, Chad, Mali, Mauritania, Niger), the Boko Haram in Nigeria and Cameroon; rebellions in Angola (1991-2002), Liberia (1999-2003), Côte d'Ivoire (2002-2010), and the Democratic Republic of the Congo (since 2000). We do not include the variable democracy because we analyse the impact of democracy on SPI in the second part.

Another specificity of our SPI index is that the sample is constituted only by ss A countries (47, see table 2) The SPI of Alesina and Perotti (1996), Gupta (1990), Venieris and Gupta (1986) and Hibbs (1973) cover the period of 1960-1985; our index is from 1990 to 2018 . This difference 
TABLE 3 Principal Components (Eigenvalues)

\begin{tabular}{lrrr}
\hline Component & Eigenvalue & Proportion & Cumulative \\
\hline СОМР 1 & 2.840 & 0.284 & 0.284 \\
СОМР2 & 2.298 & 0.230 & 0.514 \\
СОМР 3 & 1.469 & 0.147 & 0.661 \\
СОМР 4 & 0.977 & 0.098 & 0.758 \\
СОМР5 & 0.781 & 0.078 & 0.836 \\
СОМР6 & 0.629 & 0.063 & 0.899 \\
СОМР7 & 0.411 & 0.041 & 0.940 \\
СОМР 8 & 0.314 & 0.031 & 0.972 \\
СОМР9 & 0.197 & 0.020 & 0.991 \\
СОМР10 & 0.086 & 0.009 & 1.000 \\
\hline
\end{tabular}

of the period makes difficult the comparison of this SPI with our SPI. The two periods, 1960-1985 and 1990-2018, are very different in terms of political events in SSA. 1990 is an important date for democracy in ss A. During that period, most ss a countries, after many years of single-party rule and dictatorship, adhered to political pluralism, multiparty politics, freedom of expression, and the state of law.

We start the PCA method with the matrix of correlations between the ten variables. The most correlated variables are NDEATH - REPRESS NKILL; SCOUP1 - ATCOUP2 - ASSASSEX. As some variables are highly correlated, we can apply the PCA method ${ }^{6}$ using fewer than ten components. Normalised PCA is used because all variables are not on the same scale. It is the case of the regime durability whose highest value is 37 and the number of persons killed which are thousands. Thus the variables are standardized.

After the normalisation of the variables, we determine the eigenvalues of the ten components. The components are new variables, linear combinations of the initial variables, and not correlated with each other (they are orthogonal to each other; each has information that is not explained by the others).

Based on the Kaiser's (1960) criterion, which recommends retaining those components with eigenvalues equal to or higher than 1 (the variance of each standardised variable), we retain four components which explain $75.8 \%$ of the total inertia.

To interpret the new axes, we use the circle of correlations (between 


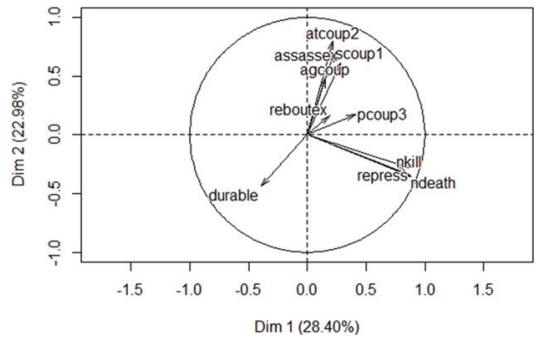

FIGURE 1 Variables Factor Map (PCA)

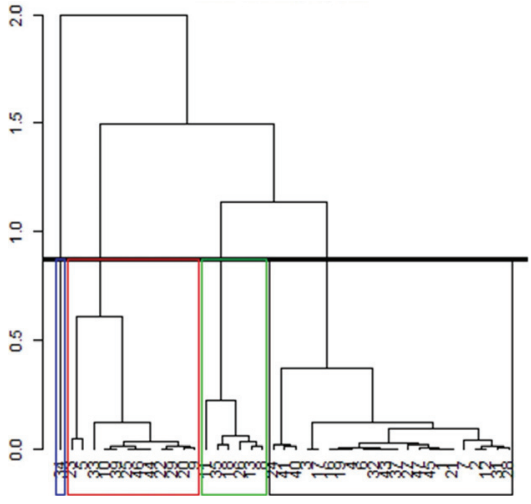

FIGURE 2 Dendrogram Showing the Partition of Countries (1990-2018)

the variables and between each variable and the first two components) of the variables factor map. The variables are represented in a plane by the first two components (figure 1).

Following the variables factor map ( $\mathrm{PCA}$ ), we can group the variables into three: DURABLE; NKILL-REPRESS-NDEATH; REBOUTEXPCOUP3-ATCOUP2-ASSASSEX-SCOUP1-AGCOUP.

When we take the first axis as reference (the horizontal axis), the variables NKILL, REPRESS and NDEATH are orthogonal to the variable durable. The first axis opposes the killings to the regime durability in the SPI. The killings are not linked to the duration of a regime.

When we take the second axis as reference (the vertical axis), the variables REBOUTEX, PCOUP3, ATCOUP2, ASSASSEX, SCOUP1, and AGCouP are opposed to the variable durable. The more coup d'état there is, the less the duration of a regime is. It means that the alternation in power in ss A takes place in several cases by coup détat. There are two ways to change a regime in office: the change can appear according to the law or following a coup d'état.

\section{PCA, HIERARCHICAL CLUSTERING AND PARTITIONAL CLUSTERING}

In addition to PCA for constructing the SPI index, we use two other methods: Hierarchical Clustering, also called Ascending Hierarchical Clustering (A HC), and Partitional Clustering. These three standard methods put together constitute the Hierarchical Clustering on Principal Components (hereinafter HCPC) approach. The objective of HCPC is 


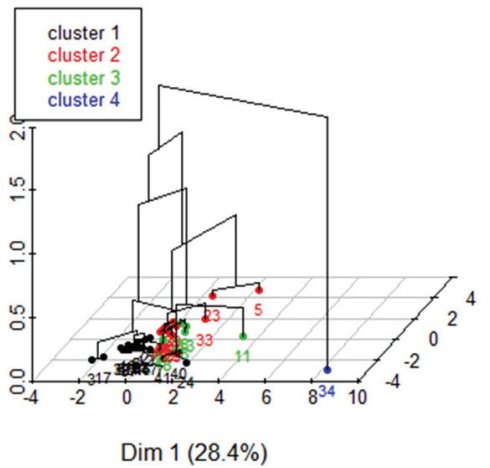

FIGURE 3 Hierarchical Clustering

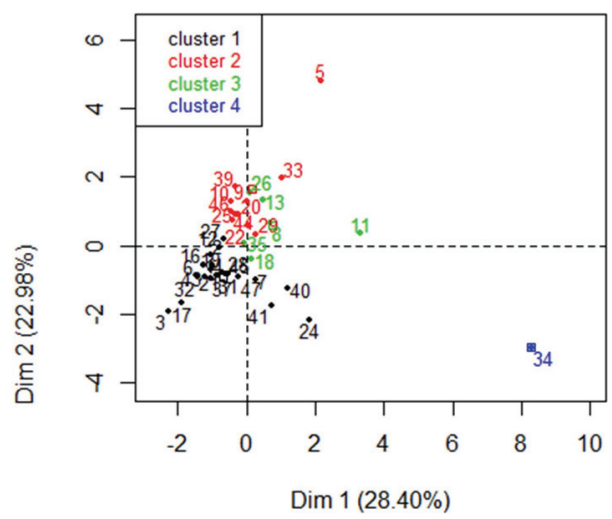

FIGURe 4 Partitioning in K-clusters (1990-2018)

to study the similarities and differences between countries from a multidimensional point of view (Lê, Josse, and Husson 2008; Husson, Josse, and Pages 2010).

The ascending hierarchical clustering is represented graphically by a tree (diagram) called a dendrogram. The number of groups (four in our case) in the hierarchical clustering is the number of PCA components. We use the Euclidean criterion for the distance and the Ward method for the agglomeration to build the dendrogram.

The third method is partitional clustering. Partitioning is used to divide the countries into several groups. A partition is good when countries of the same class are closed, and countries of two different classes are distant. We use the K-means method; as it also uses the Euclidean criterion for the distance. The number of communities determined by PCA is also used to partition the sample into four subgroups.

Using the first two principal components, the factor map represents the four clusters. A square represents the barycentre of each cluster, and the individuals are coloured according to their cluster.

After performing the clustering, we describe each cluster using three approaches: (1) We describe each cluster according to the variables in table 5; (2) We describe each cluster according to the principal components in table 6; (3) We also analyse the distance between each country and the centre of its cluster in table 7 .

According to table 6, the four clusters are represented by different components; two clusters chosen randomly do not have the same principal components. It means that the clustering has been done well: countries 
TABLE 4 Classification of the countries according to SPI (1990-2018)

\begin{tabular}{lcll}
\hline Cluster A (blue) & Cluster B (green) & Cluster C (red) & Cluster D (black) \\
\hline 34 Nigeria & 8 Central African & 5 Burundi & 1 Angola \\
& Republic & 9 Chad & 2 Benin \\
& 11 Democratic & 10 Comoros & 3 Botswana \\
& Republic & 20 The Gambia & 4 Burkina Faso \\
of the Congo & 22 Guinea & 6 Cabo Verde \\
& 13 Côte d'Ivoire & 23 Guinea-Bissau & 7 Cameroon \\
18 Ethiopia & 25 Lesotho & 12 Republic \\
26 Liberia & 29 Mali & of the Congo \\
35 Rwanda & 33 Niger & 16 Eritrea \\
& 39 Sierra Leone & 17 Eswatini \\
& 44 Togo & 19 Gabon \\
& 46 Zambia & 21 Ghana \\
& & 24 Kenya \\
& & 27 Madagascar \\
& & 28 Malawi \\
& & 31 Mozambique \\
& & 32 Namibia \\
& & 40 Senegal \\
& & 41 South Africa \\
& & 43 Tanzania \\
& & 47 Zimbabwe \\
& &
\end{tabular}

Notes The hierarchical clustering on the factor map is in figure 3 .

have been grouped according to their similarities (intragroup) and according to their differences (intergroup).

We interpret the three tables, 5, 6, and 7, considering the clusters.

Cluster A: The country from cluster A (Nigeria) has a high sPI since the averages of the variables (NKILL, REPRESS, NDEATH, PCOUP3) of this cluster are much higher than the average for all the countries. It means that a lot of killings characterises the SPI of Nigeria: more than 10,000 deaths during the religious conflict in the 1990s, more than 1,500 deaths during community conflict (Ijaw, Itsekeri), and another religious conflict in 2000 with more than 55,000 deaths. The Boko Haram has killed more than 1 million people in Nigeria. Nigeria is represented only by the component 1 . The characteristic of component 1 is the killings.

Cluster B: The countries from cluster B have a high SPI since the averages of the clusters' variables (REBOUTEX, ASSASSEX) are much higher than the average for all the countries. It means that the SPI of cluster 
TABLE 5 Description of Each Cluster According to the Variables

\begin{tabular}{|c|c|c|c|c|c|}
\hline \multicolumn{3}{|c|}{ Cluster A } & \multicolumn{3}{|c|}{ Cluster B } \\
\hline (1) & (2) & (3) & (1) & (2) & (3) \\
\hline NKILL & 25250 & 1763.171 & REBOUTEX & 1.000 & 0.146 \\
\hline REPRESS & 673 & 83.683 & ASSASSEX & 0.500 & 0.146 \\
\hline NDEATH & 48360 & 4545.585 & & & \\
\hline $\mathrm{PCOUP}_{3}$ & 3 & 0.781 & & & \\
\hline \multicolumn{3}{|c|}{ Cluster C } & \multicolumn{3}{|c|}{ Cluster D } \\
\hline (1) & (2) & (3) & $(1)$ & (2) & (3) \\
\hline $\operatorname{SCOUP} 1$ & 1.333 & 0.512 & DURABLE & 350.591 & 283.415 \\
\hline ATCOUP 2 & 3.750 & 1.610 & ASSASSEX & 0.000 & 0.146 \\
\hline PCOUP 3 & 1.500 & 0.780 & PCOUP 3 & 0.409 & 0.780 \\
\hline \multirow[t]{3}{*}{ AGCOUP } & 0.250 & 0.073 & REBOUTEX & 0.000 & 0.146 \\
\hline & & & ATCOUP 2 & 0.318 & 1.610 \\
\hline & & & SCOUP 1 & 0.045 & 0.512 \\
\hline
\end{tabular}

Notes Column headings are as follows: (1) variable, (2) mean in category, (3) overall mean.

TABLE 6 Description of Each Cluster According to the Component

\begin{tabular}{|c|c|c|c|c|c|}
\hline \multicolumn{3}{|c|}{ Cluster A } & \multicolumn{3}{|c|}{ Cluster B } \\
\hline (1) & (2) & (3) & (1) & (2) & (3) \\
\hline 1 & 8.290 & $5.26 e^{-17}$ & 3 & -2.309 & $-2.105 e^{-16}$ \\
\hline \multicolumn{3}{|c|}{ Cluster C } & \multicolumn{3}{|c|}{ Cluster D } \\
\hline (1) & (2) & (3) & (1) & (2) & (3) \\
\hline 2 & 1.648 & $-3.808 e^{-16}$ & 1 & -0.670 & $5.263 e^{-17}$ \\
\hline 3 & 0.950 & $-2.105 e^{-16}$ & 2 & -0.926 & $-3.808 e^{-16}$ \\
\hline
\end{tabular}

Notes Column headings are as follows: (1) variable, (2) mean in category, (3) overall mean.

$B$ is characterised by rebellion and assassination of the executive. Considering the distance from the barycentre, the countries which characterise Cluster B are the Central African Republic (rebellion from 2004 to 2013), Rwanda (rebellion from 1990 to 1994; the assassination of the president Juvénal Habyarimana in 1994), Liberia (assassination of the president Samuel Kanyon Doe in 1990), Côte d'Ivoire (rebellion in 2002) and Ethiopia (the ONLF rebellion since 1984). Component 3 is characterised by rebellion and coups détat (successful or not). The countries of cluster 
TABLE 7 Description of Each Cluster According to the Distance between Countries in the Same Cluster

\begin{tabular}{|c|c|c|c|c|c|c|c|c|c|}
\hline \multicolumn{5}{|c|}{ Cluster A } & \multicolumn{5}{|c|}{ Cluster B } \\
\hline 34 & & & & & 8 & 35 & 26 & 13 & 18 \\
\hline 0 & & & & & 0.407 & 1.119 & 1.271 & 1.311 & 1.353 \\
\hline \multicolumn{5}{|c|}{ Cluster C } & \multicolumn{5}{|c|}{ Cluster D } \\
\hline 9 & 39 & 10 & 25 & 46 & 1 & 45 & 31 & 37 & 21 \\
\hline 0.434 & 0.554 & 0.851 & 0.881 & 0.941 & 0.331 & 0.355 & 0.403 & 0.435 & 0.461 \\
\hline
\end{tabular}

B have their coordinates in component 3 only.

The countries from cluster D are characterised by below-average SPI, since the variables (DURABLE, ASSASSEX, PCOUP3, REBOUTEX, ATCOUP2, SCOUP1) of this cluster are smaller than the average for all the countries. A regime's duration and coups d'état (successful or not) characterise the SPI of cluster D. The countries which characterise cluster $\mathrm{D}$ are Angola ( 38 years of José Eduardo dos Santos in power), Uganda (Yoweri Museveni, with 35 years in office), Mozambique (Joaquim Chissano, with 19 years in office), Senegal (Abdou Diouf, with 17 years in office), Ghana (20 years of Jerry Rawlings in power). The countries of cluster D are represented by the components 1 and 2 . The component 2 is characterised by the regime's duration.

Cluster C: The countries from cluster $\mathrm{C}$ have a high SPI, since the averages of the variables of the cluster (SCOUP1, ATCOUP2, PCOUP3, AGCOUP) are much higher than the average for all the countries. This means that the SPI of cluster $\mathrm{C}$ is characterised by coups détat (successful or not). The countries which characterise cluster $\mathrm{C}$ are Chad (coups détat in 1990, 2004, 2006), Sierra Leone (coup d'état in 1992), Comoros (coups d'état in 1995, 1999), Lesotho (coup d'état in 2014) and Zambia (coup deétat in 1997). The countries of cluster $C$ are represented by the components 2 and 3.

All these results are confirmed by each country's position on the factor map and the position of the variables on the variables factor map.

\section{MODEL SPECIFICATION}

Following Alesina and Perotti (1996), the empirical model is specified in equation (2) as follows:

$$
\operatorname{SPI}_{i t}=\alpha_{1} y_{i t-1}+\alpha_{2} d_{i t}+Z_{i t}^{\prime} \gamma+\theta_{i t} \text {. }
$$

In models where SPI is used, two equations are used to make the es- 
timates. In the first equation, the SPI is estimated - through a probit regression or the PCA method -, and in the second equation, we regress the SPI with an economic variable - income, GDP per capita, economic growth and investment (Hibbs 1973; Fosu 1992; Alesina and Perotti 1996; Venieris and Gupta 1986; Gupta 1990; Barro 1991; Ozler and Tabellini 1991; Benhabib and Spiegel 1992; Mauro 1993).

In our research, we use this methodology, which estimates two equations. In the first part of the methodology, we have measured spi. The equation (1), therefore, constitutes the first equation. For the second equation, we use the model of Alesina and Perotti (1996). In this second equation (equation 2), the dependent variable, SPI, is explained by income inequality $\left(y_{i t}\right)$, the level of democracy $\left(d_{i t}\right)$ and a set of control variables constituted by institutional and economic variables $\left(Z_{i t}^{\prime}\right)$ : GDP growth, Inflation, Ethnic fractionalisation, Natural Resources, Education, and Urbanisation.

\section{Income Inequality $\left(y_{i t}\right)$}

The problem of income inequality data in ss A is the scarcity of available data, the absence of administrative data and that most of the data is based on survey estimates. Household surveys routinely underestimate the income and wealth of individuals at the top of the social ladder. There are many initiatives to build an accurate income inequality database for ss A countries. $^{7}$

We adopt the Gini coefficient of the World Income Inequality Database (WIID) version 4 to measure income inequality for our model for several reasons. Data is obtained from the main available current databases: the World Bank, the Luxembourg Income Study (Lis), PovcalNet and national statistical offices, and from a large range of independent research papers. The 47 countries of our sample are present in the database. In many cases, UNU-WIDER (United Nations University World Institute for Development Economics Research) has recalculated the Gini index to be better comparable.

In models where an economic variable explains a political variable, there is the risk of joint endogeneity because of the bilateral relationship between the two variables. In our case inequality causes SPI, and SPI is also responsible for SPI. This bilateral relationship creates a problem of endogeneity. To overcome the problem of endogeneity, Londregran and Poole (1990; 1991), and Alesina et al. (1996) estimate a system of two equations in which the two endogenous variables are investment/economic 
growth and the SPI. To resolve joint endogeneity, we take the lagged values of the income inequality that measure this variable at the beginning of the sample period.

\section{$\operatorname{Democracy}\left(d_{i t}\right)$}

We choose the Freedom House Democracy Index to measure the democracy of our sample because its characteristics are necessary for our research. Civil liberties and political rights are two properties which are very important for democracy in ss A countries. The political rights are based on the electoral process, the political pluralism, participation, and government functioning. The indicators which composed the civil liberties are grouped into four categories: the freedom of expression and belief; the associational and organisational rights; the rule of law; and the personal autonomy and individual rights.

We calculate the mean of Freedom House's political rights and civil liberties indices, and we take the difference of the percentage to 100 to obtain the Democracy Index. The higher the index is, the more democratic the country, and vice versa. The index is available for all our sample countries from 1978 to 2018, and it is annual. Freedom House's survey methodology is based on standards applicable to all countries and territories, regardless of geographic location, ethnic or religious composition, or level of economic development. It makes comparisons across countries possible.

\section{Institutional and Economic Variables $\left(Z_{i t}^{\prime}\right)$}

We expect that SPI decreases with economic development (Håvard and Sambanis 2006). Wealthier countries have more resources at their disposal that could be invested in social insurance and other forms of redistribution to alleviate social tensions. Economic development is measured through GDP growth (Schneider and Wiesehomeier 2008). Since 2000, African countries have recorded high growth rates. Out of the ten fastest-growing countries in the world, six are in Africa (South Sudan 8.2\%; Rwanda 8.1\%; Côte d'Ivoire 7.3\%; Ethiopia 7.2\%; Senegal 6.8\%; Benin 6.7\%; Uganda 6.2\%) This growth rate rebounded from $1.4 \%$ in 2009 to $3.4 \%$ in 2019 (World Bank 2019). This performance should contribute significantly to income levelling and wealth redistribution, thus reducing SPI.

The variables GROWTH, INFLATION, N_RESOURCES and URBANISATION are measured by the GDP growth, Inflation, Total natural re- 
sources rents (\% of GDP) and Urban population (\% of the total population) of the World Development Indicators (hereinafter WDI) of the World Bank.

Weak institutions are fertile ground for SPI. This increases the likelihood of political unrest and encourages citizens to resort to violence rather than focusing on economic and socially profitable activities (Anthony-Orji et al. 2019). Zelao (2000), in his argument on the question, reveals that the moods and rebellions in Africa most often come from weaknesses in the political institutions. To take into account the quality of the institutions in our regression, we insert the variable EDUCATION. The Educational attainment (at least completed lower secondary, population older than 25 years, percentage, cumulative) of the WDI of the World Bank measures the variable EDUCATION.

Esteban and Debraj (1999; 2008) discovered that highly fractionalised societies are prone to conflict. To test the impact of ethnic division on SPI within our sample, we use the ethnic FRACTIONALISATION index of Fearon (2003) based on the Atlas Narodov Mira (Bruk and Apenchenko 1964) dataset. The ethnic fractionalisation variable measures the probability that two randomly selected individuals will not belong to the same ethnolinguistic group. The FRACTIONALISATION index is ranged from o to 1 .

\section{ESTIMATION OF EQUATION (2) BY OLS}

After presenting the model, we proceed to econometric estimates (table 8).

\section{The Estimate (A)}

The coefficient of INCOME INEQUALITY is positive and significant. INCOME INEQUALITY has a positive and significant impact on SPI. In the 47 countries that make up our sample, inequality is one of the causes of instability. This finding corroborates Acemoglu and Robinson (2001). It can nevertheless be noted that the impact of inequality on SPI, although significant, is small (0.02). According to these results, the cause of the SPI cannot be fully attributed to income inequality. In addition to inequality, other factors causing SPI should be explored.

The variable DEMOCRACY is significant, and the coefficient is positive: 0.68 . This result indicates that in ss A countries, democracy explains SPI. The coefficient for inequality is 0.02 , while the coefficient for democracy is 0.68 . Democracy, in its conception, promotes elections without vi- 
TABLE 8 Estimation by OLS of the Equation (2)

\begin{tabular}{|c|c|c|c|}
\hline Variable & A & B & $\mathrm{C}$ \\
\hline INCOME INEQUALITY & $0.02^{\star * *}(0.33)$ & $0.02^{\star * *}(0.00)$ & $-0.07^{* * *}(0.37)$ \\
\hline DEMOCRACY & $0.68^{\star *}(0.01)$ & $0.44^{* *}(0.04)$ & $3.31^{\star * *}(0.07)$ \\
\hline GROWTH & & $-0.06 \quad(0.28)$ & $0.06^{* *}(0.47)$ \\
\hline INFLATION & & $-0.01^{\star} \quad(0.09)$ & $-0.01 \quad(0.11)$ \\
\hline N_RESOURCES & & & $-0.3 e^{-8} \quad(0.15)$ \\
\hline URBANISATION & & & $-0.03^{\star *}(0.33)$ \\
\hline EDUCATION & & & $-0.09^{* * *}(0.31)$ \\
\hline FRACTIONALISATION & & & $0.63 \quad(0.43)$ \\
\hline Observations & 74 & 74 & 70 \\
\hline
\end{tabular}

NOTES Robust standard errors are in parentheses; ${ }^{* * *}$ significant at $1 \%,{ }^{* *}$ significant at $5 \%,{ }^{*}$ significant at $10 \%$.

olence, so theoretically, this coefficient should be negative. Nevertheless, several studies ${ }^{8}$ confirmed the result we obtained.

This positive coefficient of the DEMOCRACY variable could be explained in several ways. ss a countries have not yet assimilated democracy, or they have not yet cultivated a culture of democracy. ss A countries are said to be countries of a new democracy. These countries are still learning about democracy, hence stumbling on this path of initiation to democracy.

Another reason for the positive impact of democracy on the SPI could be that ssa countries do not yet have the prerequisite to be democratic. To opt for democracy, you need a minimum of achievements at the economic level (an acceptable level of income per capita, a low poverty rate, etc.) and at the social level (good social cohesion, national unity and a good level of education).

The third reason could be that democracy is not the right system, least not yet, for African countries. Other political systems (dictatorship, monarchy, etc.) could allow ss A countries to reduce SPI.

\section{The Estimate (B)}

In this second regression, in addition to INCOME INEQUALITY and DEMOCRACY, we add INFLATION and GDP growth. The coefficients of INCOME INEQUALITY and DEMOCRACY remain significantly positive. When it comes to INFLATION, the coefficient is significant and negative. This negative sign does not conform to economic theory because inflation is supposed to cause unrest and uprisings. GDP growth is not significant. 


\section{The Estimate (C)}

In this regression, we take into account all the variables of the model. Whereas DEMOCRACY remains positive and significant, INCOME INEQUALITY is negative. The variable INFLATION is not significant. The GDP growth coefficient is positive and significant. The economic growth that is supposed to improve the populations' living conditions increases the SPI in SSA. This result raises questions about the distribution of the fruits of growth. If the distribution of wealth is not done well, it can create income inequality, which causes SPI.

The sign of EDUCATION is negative and significant. Education and training reduce SPI. The higher the intellectual level of a country's population is, the less the SPI. The theoretical and empirical literature does not recommend the negative sign of NATURAL RESOURCES. The Dutch disease theory stipulates that the richer a country is in natural resources, the more unstable it will be. URBANISATION helps to reduce SPI. This could be explained by the fact that urban areas are more docile to the central government and its representatives. The more the villages modernise and the cities grow, the more democracy there is. Huntington (1968) and Berg and Sachs (1988) argue the opposite: urbanisation leads to social demand and increased redistributive politics. The variable FRACTIONALISATION is not significant.

\section{Conclusion}

Our research's main objective is to analyse income inequality as a determinant of SPI for a sample of 47 Ss A countries over the period from 1990 to 2018. In this study, democracy has been inescapable both theoretically and empirically.

Our econometric approach took place in two steps. In the first step, we used the Hierarchical Clustering on Principal Components approach (PCA plus hierarchical clustering and partitioning) to measure the SPI Index and group the countries according to their similarity in SPI. In the second step, we estimated a linear panel model using the oLs method to analyse income inequality's impact on the SPI.

The SPI analysis allows us to conclude that the killings are not linked to the duration of a regime and that the duration of a regime reduces if coups d'état (successful or not) are rampant. Many killings characterise the SPI of Nigeria. That of cluster B is characterised by rebellion and assassination of the executive. That of cluster $\mathrm{D}$ is characterised by a 
TABLE 9 Correlation Matrix

\begin{tabular}{|c|c|c|c|c|c|c|c|c|c|c|}
\hline Variables & (1) & (2) & (3) & (4) & (5) & (6) & (7) & (8) & (9) & (10) \\
\hline (1) SCOUP 1 & 1.000 & & & & & & & & & \\
\hline (2) ATCOUP2 & 0.614 & 1.000 & & & & & & & & \\
\hline (3) $\mathrm{PCOUP} 3$ & 0.298 & 0.196 & 1.000 & & & & & & & \\
\hline (4) AGCOUP & 0.178 & 0.184 & 0.243 & 1.000 & & & & & & \\
\hline (5) REBOUTEX & -0.007 & 0.108 & -0.181 & -0.116 & 1.000 & & & & & \\
\hline (6) ASSASSEX & 0.223 & 0.477 & -0.039 & 0.351 & 0.351 & 1.000 & & & & \\
\hline (7) DURABLE & -0.281 & -0.310 & -0.069 & -0.208 & -0.210 & -0.225 & 1.000 & & & \\
\hline (8) NDEATH & -0.067 & -0.023 & 0.134 & -0.080 & 0.197 & 0.127 & -0.152 & 1.000 & & \\
\hline (9) REPRESS & -0.002 & -0.071 & 0.293 & 0.006 & 0.048 & -0.023 & -0.155 & 0.878 & 1.000 & \\
\hline (10) NKILL & 0.031 & -0.047 & 0.291 & 0.008 & 0.029 & 0.088 & -0.186 & 0.775 & 0.793 & 1.000 \\
\hline COMP 1 & 0.136 & 0.129 & 0.244 & 0.091 & 0.113 & 0.166 & -0.233 & 0.516 & 0.522 & 0.514 \\
\hline COMP 2 & 0.458 & 0.528 & 0.114 & 0.316 & 0.107 & 0.404 & -0.288 & -0.222 & -0.236 & -0.186 \\
\hline СOMP 3 & 0.224 & 0.006 & 0.548 & 0.234 & -0.651 & -0.349 & 0.146 & -0.146 & 0.056 & 0.049 \\
\hline COMP 4 & -0.438 & -0.297 & -0.047 & 0.767 & -0.092 & 0.346 & 0.033 & -0.013 & -0.006 & 0.020 \\
\hline
\end{tabular}

FIGURE 5 Scree Plot

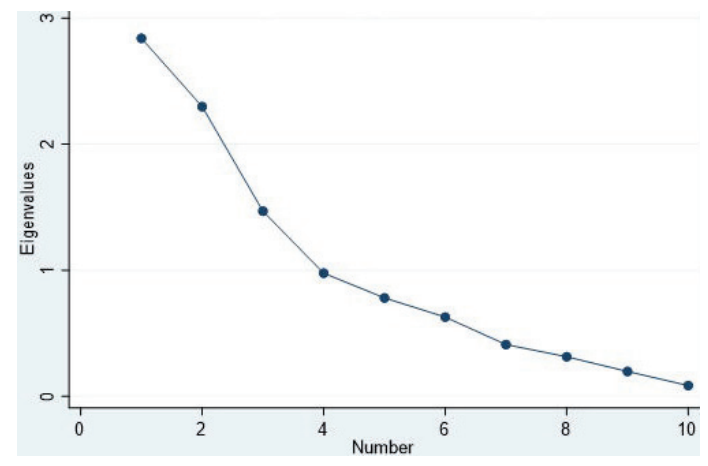

regime's duration in power and coups détat (successful or not). That of cluster $\mathrm{C}$ is characterised by coups d'état (successful or not).

The econometric estimate results indicate that income inequality in ss a countries has a significant and positive impact on the SPI. We find these results in the presence of democracy, inflation and economic growth. Our results also reveal that democracy causes SPI more than income inequality does. Democracy is largely responsible for SPI in SSA countries. Democracy, in its conception, is to reduce SPI. This result could be explained by the fact that ss A countries are new democracies or that these countries are still learning the rules of democracy or democracy is not the right system, least not yet, for African countries. The GDP growth that is supposed to improve the populations' living conditions increases 
the SPI in SSA. This result raises questions about the distribution of the fruits of growth. Education reduces SPI.

One of our research results is that democracy positively affects SPI, while in theory, democracy should reduce SPI. Does this result pose the following problem: are ss A countries able to apply the democratic system? Do these countries fulfil all the conditions that apply to democracy? Subsequent research that analyses the determinants of democracy in ss A could answer these questions. Further research could analyse the relationship between SPI and income inequality for ss A countries grouped according to the coloniser's origin.

\section{Notes}

1 Defined as those living on less than 1.90 dollar a day (Ferreira et al. 2016).

2 Chancel et al. (2019) said: 'Africa has the highest gap between average incomes of the top $10 \%$ and incomes of the bottom $50 \%$ : average incomes of the top $10 \%$ are about 30 times higher than those of the bottom 50\%.'

3 This approach is used by several authors: Venieris and Gupta (1986), Gupta (1990), Barro (1991), Ozler and Tabellini (1991), Benhabib and Spiegel (1992), Mauro (1993).

4 Husson, Josse, and Pages (2010, 2): 'PCA can be viewed as a denoising method which separates signal and noise.'

5 The variables are: Assass (the number of politically motivated assassinations); DEATH (the number of people killed in conjunction with phenomena of mass domestic violence, as a fraction of the total population); scoup (the number of successful coups); UCOUP (the number of attempted but unsuccessful coups); DEM (a dummy variable that takes the value of 1 in democracies, 0.5 in 'semi-democracies' and o in dictatorships).

6 The other elements of the PCA method (the matrix of correlation, the coordinates of the variables, and the eigenvalues) are presented in table 9 and figure 5 .

7 The most used in the economic literature are the World Inequality Indicators Database (WIID) of the United Nations University World Institute for Development Economics Research (UNU-WIDER); The Standardised World Income Inequality Database (swird); The Luxembourg Income Study Database (LIs); The World Inequality Database (WID) of the World Inequality Report; and the World Development Indicators (WDI) of the World Bank.

8 Keech (1995) talks about the costs of democracy when it has undesirable effects on society. SPI could, therefore, be seen as a cost of democracy. For Alesina and Rodrik (1995), transitional democracies (the period preceding 
the democratic period, for example, authoritarian and dictatorial regimes) constitute the most vulnerable types of power (social, political and economic instability). They show that it is the case in Latin American countries.

\section{References}

Acemoglu, D., and J. Robinson. 2001. 'A Theory of Political Transitions.' The American Economic Review 91 (4): 938-63.

Alesina, A., and R. Perotti. 1996. 'Income Distribution, Political Instability and Investment.' European Economic Review 40 (6): 1203-28.

Alesina, A., and D. Rodrik. 1995. 'Distributive Politics and Economic Growth.' The Quarterly Journal of Economics 109 (2): 465-90.

Alesina, A., O. Sule, R. Nouriel, and S. Phillip. 1996. 'Political Instability and Economic Growth.' Journal of Economic Growth 1 (2): 189-211.

Angelopoulos, K., and G. Economides. 2008. 'Fiscal Policy, Rent Seeking, and Growth under Electoral Uncertainty: Theory and Evidence from the OECD.' Canadian Journal of Economics 41 (4): 1375-405.

Anthony-Orji, O. I., A. Orji, J. E. Ogbuabor, and E. O. Nwosu. 2019. 'Do Financial Stability and Institutional Quality Have Impact on Financial Inclusion in Developing Economies? A New Evidence from Nigeria International.' International Journal of Sustainable Economy 11 (1): 1840.

Arulampalam, W., M. Devereux, and G. Maffini. 2010. 'The Direct Incidence of Corporate Income Tax on Wages.' IZA DP 5293, Institute of Labor Economics, Bonn.

Bardhan, P., and D. Mookherjee. 2010. 'Determinants of Redistributive Politics: An Empirical Analysis of Land Reforms in West Bengal, India.' American Economic Review 100 (4): 1572-60o.

Barro, R. J. 1991. 'Economic Growth in a Cross Section of Countries.' The Quarterly Journal of Economics 106 (2): 407-43.

Barro, R. J. 1999. 'Determinants of Democracy' Journal of Political Economy 107 (6): $158-83$.

Beck, T., R. Levine, and N. Loayza. 200o. 'Finance and the Sources of Growth.' Journal of Financial Economics 58 (1-2): 261-300.

Benhabib, J., and M. Spiegel. 1992. 'The Role of Human Capital in Economic Development: Evidence form Aggregate Cross-Country Regional U.S. Data.' Working Papers 92-46, C.V. Starr Center for Applied Economics, New York University, New York.

Berg, A., and J. Sachs. 1988. 'The Debt Crisis: Structural Explanations of Country Performance.' NB E R Working Paper 2607, National Bureau of Economic Research, Cambridge, mA. 
Bourguignon, F., and C. Morrisson. 1998. 'Inequality and Development: The Role of Dualism.' Journal of Development Economics 57 (2): 233-57.

Bruk, S. I., and V. S. Apenchenko. 1964. Atlas narodov mira. Moscow: Glavnoe Upravlenie Geodezii I Kartografi.

Chancel, L., D. Cogneau, A. Gethin, and A. Myczkowski. 2019. 'Ten Facts about Inequality in Advanced Economies.' Working Paper 2019/15, World Inequality Lab, Paris.

Collier, P. 2007. 'Poverty Reduction in Africa.' Proceedings of the National Academy of Sciences 104 (43): 16763-8.

Cukierman, A., S. Edwards, and G. Tabellini. 1992. 'Seigniorage and Political Instability'. American Economic Review 82 (3): 537-55.

Dabla-Norris, E., K. Kochhar, N. Suphaphiphat, F. Ricka, and E. Tsounta. 2015. Causes and Consequences of Income Inequality: A Global Perspective. SDN/15/13, International Monetary Fund, Washington, DC.

Dixit, A., and J. Londregan. 1996. 'The Determinant of Success of Special Interests in Redistributive Politics.' The Journal of Politics 58 (4): 113255.

Dixit, A., and J. Londregan. 1998. 'Fiscal Federalism and Redistributive Politics.' Journal of Public Economics 68 (2): 153-80.

Dutt, P., and M. Devashish. 2008. 'Inequality and the Instability of Polity and Policy. The Economic Journal 118 (531): 1285-314.

Edwards, S., and G. Tabellini. 1991. 'Explaining Fiscal Policies and Inflation in Developing Countries.' Journal of International Money and Finance 10 (1): $16-48$.

Esteban, J., and R. Debraj. 1999. 'Conflict and Distribution.' Journal of Economic Theory 87 (2): 379-415.

Esteban, J., and R. Debraj. 2008. 'Polarisation, Fractionalisation and Conflict.' Journal of Peace Research 45 (2): 163-82.

Fearon, J. D. 2003. 'Ethnic and Cultural Diversity by Country'. Journal of Economic Growth 8 (2): 195-222.

Ferreira, F., S. Chen, A. Dabalen, Y. Dikhanov, N. Hamadeh, D. Jolliffe, A. Narayan, E. Prydz, A. Revenga, P. Sangraula, U. Serajuddin, and N. Yoshida. 2016. 'A Global Count of the Extreme Poor in 2012: Data Issues, Methodology and Initial Results.' The Journal of Economic Inequality 14:141-72.

Fosu, A. 1992. 'Political Instability and Economic Growth: Evidence from Sub-Saharan Africa.' Economic Development and Cultural Change 40 (4): 829-41.

Fosu, A. 2002. 'Political Instability and Economic Growth: Implications of Coup Events in SubSaharan Africa.' American Journal of Economics and Sociology 61 (1): 329-48.

Gasiorowski, M. J. 1995. 'Economic Crisis and Political Regime Change: 
An Event History Analysis.' American Political Science Review 89 (4): 882-97.

Gupta, D. K. 1990. The Economics of Political Violence: The Effect of Political Instability on Economic Growth. New York: Praeger.

Håvard, H., and N. Sambanis. 2006. 'Sensitivity Analysis of Empirical Results on Civil War Onset.' Journal of Conflict Resolution 50 (4): 508-35.

Hibbs, D. 1973. Mass Political Violence: A Cross-Sectional Analysis. New York: Wiley.

Huntington, S. P. 1968. Political Order in Changing Societies. New Haven, С : Yale University Press.

Husson, F., J. Josse, and J. Pagès. 2010. 'Principal Component Methods Hierarchical Clustering - Partitional Clustering: Why Would We Need to Choose for Visualising Data?' Technical Report, Agrocampus Ouest, Rennes.

Kaiser, H. F. 1960. 'The Application of Electronic Computers to Factor Analysis.' Educational and Psychological Measurement 20 (1): 141-51.

Kaufmann, D., A. Kraay, and P. Zoido-Lobaton. 1999. 'Governance Matters.' Policy Research Working Paper Series 2196, The World Bank, Washington, DC.

Keech, W. R. 1995. Economic Politics: The Costs of Democracy. New York: Cambridge University Press.

Keefer, P., and S. Knack. 200o. 'Polarisation, Politics, and Property Rights: Links between Inequality and Growth.' Policy Research Working Paper Series 2418, The World Bank, Washington, DC.

Kouakou, A. 2010. 'Impact de l'instabilité socio-politique sur les investissements publics et privés en Côte d'Ivoire.' Mémoire de DESS_GPE 11, Université de Cocody Côte d'Ivoire, Abidjan.

Kormendi, R. C., and P. G. Meguire. 1985. 'Macroeconomic Determinants of Growth: Cross-Country Evidence.' Journal of Monetary Economics 16 (2): 141-63.

Krueger, A. O. 2002. 'Supporting Globalization.' Remarks at the 2002 Eisenhower 'National Security Conference on National Security for the 21st Century:' Anticipating Challenges, Seizing Opportunities, Building Capabilities, Washington, DC, 26 September.

Krugman, P. 2007. The Conscience of a Liberal New York: Norton.

Lalime, T. 2010. 'Croissance économique et instabilité politique en Haïti (1970-2008)'. Master Thesis, University of Montreal.

Lê, S., J. Josse, and F. Husson. 2008. 'FactoMineR: An R Package for Multivariate Analysis.' Journal of Statistical Software 25 (1): 1-18.

Lindbeck, A., and J. Weibull. 1987. 'Balanced-Budget Redistribution as the Outcome of Political Competition.' Public Choice 52 (3): 273-97. 
Londregan, J., and K. Poole. 1990. 'Poverty, The Coup Trap, and The Seizure of Executive Power.' World Politics 42 (2): 151-83.

Londregan, J., and K. Poole. 1991. 'The Seizure of Executive Power and Economic Growth: Some Additional Evidence.' NB E R Working Paper 4173, National Bureau of Economic Research, Cambridge, MA.

Mauro, P. 1993. 'Essays on Country Risk, Asset Markets and Growth.' PhD Thesis, Harvard University.

Ozler, S., and G. Tabellini. 1991. 'External Debt and Political Instability.' NBER Working Paper 3772, National Bureau of Economic Research, Cambridge, MA.

Perotti, R. 1996. 'Growth, Income Distribution and Democracy: What the Data Say. European Economic Review 40 (6): 1203-28.

Persson, T., and G. Tabellini. 2000. Political Economics. Cambridge: мIт Press.

Przeworski, A., J. Cheibub, F. Limongi, and M. Alvarez. 1996. 'What Makes Democracy Endure?' Journal of Democracy 7 (1): 39-55.

Schneider, G., and N. Wiesehomeier. 2008. 'Political Institutions and the Diversity: Conflict Nexus, Special Issue on Polarization and Conflict.' Journal of Peace Research 45 (2): 183-203.

Treisman, D. 2000. 'The Causes of Corruption: A Cross-National Study' Journal of Public Economics 76 (3): 399-457.

Venieris, Y. P., and D. K. Gupta. 1986. 'Income Distribution and Sociopolitical Instability as Determinants of Savings: A Cross-sectional Model.' Journal of Political Economy 94 (4): 873-83.

Zelao, A. 2000. 'Autorités traditionnelles and désir d'hégémonie dans le champ politique au Nord-Cameroun.' Political Science Review 17 (2): 355-76.

World Bank. 2019. Global Economic Prospects: Darkening Skies. Washington, DC: The World Bank. 